\begin{tabular}{|l|l|l|}
\hline \multicolumn{2}{|c|}{ PublisherInfo } \\
\hline \hline PublisherName & $:$ & BioMed Central \\
\hline \hline PublisherLocation & $:$ & London \\
\hline \hline PublisherImprintName & $:$ & BioMed Central \\
\hline \hline
\end{tabular}

\title{
FOXO transcription factor stimulates repair
}

\begin{tabular}{|l|l|l||}
\hline \multicolumn{2}{|c|}{ ArticleInfo } \\
\hline \hline ArticleID & $:$ & 4457 \\
\hline \hline ArticleDOI & $:$ & $10.1186 /$ gb-spotlight-20020422-02 \\
\hline \hline ArticleCitationID & $:$ & spotlight-20020422-02 \\
\hline \hline ArticleSequenceNumber & $:$ & 123 \\
\hline \hline ArticleCategory & $:$ & Research news \\
\hline ArticleFirstPage & $:$ & 1 \\
\hline \hline ArticleLastPage & $:$ & 2 \\
\hline \hline & & RegistrationDate : 2002-4-22 \\
\hline ArticleHistory & $:$ & OnlineDate \\
\hline \hline ArticleCopyright & $:$ & BioMed Central Ltd2002-4-22 \\
\hline \hline ArticleGrants & $:$ & \\
\hline \hline ArticleContext & $:$ & 130593311 \\
\hline \hline
\end{tabular}




\section{Jonathan B Weitzman}

Email: jonathanweitzman@hotmail.com

The protein kinase Akt promotes cell survival by phosphorylating and inhibiting FOXO forkhead transcription factors. FOXO factors have been linked to stress responses and the regulation of longevity. In the April 19 Science, Hien Tran and colleagues at Boston's Children's Hospital define a role for the FOXO3a family member in the response to DNA damage (Science 2002, 296:530-534). They created a Rat-1 fibroblast cell line expressing a tamoxifen-inducible FOXO3a protein. FOXO3a expression resulted in a delay in G2-M phase of the cell-cycle and enhanced DNA repair. Tran et al. performed a microarray screen to find FOXO3a-regulated genes and identified a number of genes involved in apoptosis and cell cycle regulation. They report that FOXO3a directly regulates transcription of the GADD45A gene upon damage of cellular DNA, and the ability of FOXO3a to induce DNA repair was reduced in cells lacking GADD45A. The role of FOXO3a in DNA repair, cell-cycle regulation and apoptosis probably contributes to its effect on organism life span.

\section{References}

1. Akt promotes cell survival by phosphorylating and inhibiting a Forkhead transcription factor.

2. Science, [http://www.sciencemag.org/]

3. Children's Hospital Boston, [http://www.tch.harvard.edu]

4. AFX-like Forkhead transcription factors mediate cell-cycle regulation by Ras and PKB through p27kip1. 